\title{
CATEGORIAS MORAIS E POLÍTICA: Uma abordagem etnográfica do voto numa favela do Recife
}

\author{
Dominique Vidal
}

\author{
Pesquisadora do Centre d'Ethnologie et de Sociologie da Universidade de Lille-III; \\ Doutora em Sociologia pela Universidade de Lille-III.
}

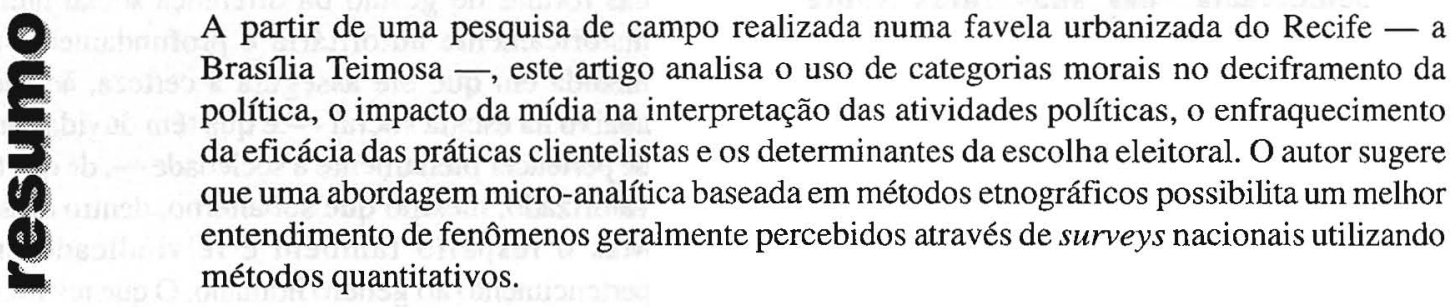

Palavras-chave: política; favela; voto; mídia; cidadania; pobreza; Recife.

$\mathbf{E}$ ste artigo ambiciona apresentar resultados de uma pesquisa de campo realizada em Brasília Teimosa, favela urbanizada do Recife, entre o início de 1992 e o final de $1994 .{ }^{1}$ Sendo o universo estudado particularmente limitado (16 913 pessoas morando numa península de 51,17 ha), não pretendemos apresentar análises válidas para o conjunto do Brasil de hoje, mas reflexões que podem servir como base de comparação para estudar o comportamento eleitoral nas camadas de baixa renda. Ao contrário dos estudos de comunidade influenciados pelo funcionalismo, não consideramos o local investigado como uma parte da totalidade cujos elementos são idênticos aos do todo. Entretanto, por mais parciais que sejam os resultados obtidos no estudo de um "pedacinho" da sociedade, uma abordagem micro-analítica baseada em métodos qualitativos (observações, entrevistas, conversas informais, convivência prolongada com o grupo investigado) possibilita um melhor entendimento de fenômenos geralmente percebidos através de surveys nacionais utilizando sofisticados métodos quantitativos. Ou seja, as análises micro e as análises macro não se opõem mas se completam, na medida em que são modos diversos de dar conta da realidade social. Com efeito, é justamente na variação de escalas de análise que encontramos a possibilidade de compreender questões complexas. ${ }^{2}$

Um carro de som que passa na rua, um panfleto passado por baixo da porta, um novo adesivo no vidro do vizinho. "Chegou a época da política" - eis como os moradores de Brasília Teimosa comentam a aparição dos primeiros sinais das campanhas eleitorais. $\mathrm{O}$ fato de identificar o período eleitoral ao conjunto das atividades políticas constitui, provavelmente, uma das chaves da relação que essa população tem com a política e, conseqüentemente, de seu comportamento eleitoral. ${ }^{3}$ Com efeito, não é possível realizar a análise do voto em Brasília Teimosa sem levar em conta, permanentemente, o lugar incerto da esfera política - no sentido de esfera distinta da vida social - no grupo estudado. Para isso, decidimos neste texto partir da importância das categorias morais em Brasília Teimosa antes de evocar o impacto da mídia no deciframento da política, o enfraquecimento das práticas clientelistas e os determinantes da escolha eleitoral.

\section{O USO DE CATEGORIAS MORAIS NO DECIFRAMENTO DA POLÍTICA}

Para se entender o comportamento eleitoral dos moradores de Brasília Teimosa, cabe enfatizar, inicialmente, o modo pelo qual eles percebem as atividades políticas e, mais especificamente, a importância das categorias morais tanto nas representações da esfera política e do papel dos políticos como na interpretação das mensagens e dos acontecimentos políticos. 
De um modo geral, a relação que os moradores de Brasília Teimosa mantêm com a política não difere, fundamentalmente, daquela dos moradores do Jardim das Camélias, bairro pobre da periferia de São Paulo estudado nos fins da década de 70. (CALDEIRA, 1984) O que eles chamam "o mundo da política" é visto como um universo totalmente separado da experiência dos pobres. Os advérbios de lugar que utilizam para designar a Prefeitura, o Senado ou o Palácio do Planalto referem-se à distância incomensurável entre o "povo" e os eleitos: "lá", "dentro", "em cima". As palavras "política" e "político" evocam práticas imorais, que o "trabalhador", cuja identidade é definida pela "honestitade" e pela "moralidade", deve evitar.

Vale notar que o retorno do regime democrático não produziu uma aproximação entre as instituições políticas e os moradores de Brasília Teimosa. Freqüentemente formulada a respeito das eleições, a expressão "a política passa, a vida continua" indica a forte indiferença quanto à natureza do regime político em vigor. Aliás, eles raramente usam as palavras "autoritarismo", "ditadura", "regime militar" e "democracia" nas suas falas sobre os acontecimentos políticos. Quando se pergunta sobre o que pensam dos regimes militar e democrático, ou se poderiam explicar a diferença entre ditadura e democracia, apenas uma minoria diferencia os dois tipos de regime, definindo a democracia como um regime de liberdade política caracterizado pela escolha dos governantes. ${ }^{4}$ Muitos, até confessam não entender o significado de tais perguntas ("sinceramente, não sei te explicar"; "não entendo nada desse negócio"). Em suma, a transição democrática não é percebida como algo relevante para interpretar o que eles consideram ser as principais mudanças da última década: o crescimento do desemprego, a inflação e o aumento da violência urbana.

No entanto, a ausência de interesse pela política não significa que os moradores de Brasília Teimosa não tenham expectativas associadas aos políticos. Ao contrário, eles têm uma idéia precisa das funções dos eleitos: "fazer para o povo", "ajudar a pobreza", "acertar os problemas do pobre". Um "político bom" é aquele que "cumpre seus deveres" ou, como um entrevistado afirmou, "é político bom se realmente trabalhasse, seja honesto e cumpre seus deveres. $\mathrm{O}$ político hoje é só para ler jornal, tomar café pequeno e criticar uns aos outros que estão na política." Respondendo sobre quais seriam os deveres de um político, o mesmo entrevistado declarou que "dever do político é trabalhar e defender quem elegeu ele."

Essa idéia dos "deveres" (ou "obrigações") dos eleitos para com os eleitores remete a um ponto essencial da maneira pela qual eles decifram a política: a imbricação constante do social e do político. Com efeito, o sentido dado ao elo político (e ao seu enfraquecimento) procede do sentido dado ao elo social. As ações dos políticos (eleitos ou não) são interpretadas através de categorias morais utilizadas na avaliação da qualidade das relações sociais com os indivíduos oriundos do mesmo grupo social, bem como com os membros das camadas sociais favorecidas. Tudo depende do comportamento.

Entre essas categorias morais, o "respeito" (palavra que remete, também, à idéia da "falta de respeito") se destaca. $^{5} \mathrm{O}$ respeito exprime o reconhecimento de que se pertence plenamente à sociedade, o reconhecimento de uma identidade social positiva ("um pai de família responsável", "uma dona de casa esforçada", "um trabalhador competente", "um rapaz de bem", "uma moça educada", "um bom brasileiro", etc.). O respeito se manifesta na idéia de que as regras necessárias ao funcionamento harmonioso da sociedade e à preservação da ordem social devem ser estritamente observadas. Essas regras (as "obrigações") dependem da posição social de cada um e referem-se às relações entre casais, parentes, amigos, vizinhos e entre patrão e empregado. Essas regras exigem contrapartidas, visto que "quem respeita tem que ser respeitado": enquanto provedor das necessidades familiares, o pai de família "manda dentro de casa"; cabendo à mãe tomar conta dos filhos, estes lhe devem obediência; cada um deve ajudar seus amigos e poder contar com eles; caso o empregado tenha um problema cuja solução não é prevista pela legislação trabalhista (falta de dinheiro para comprar um remédio, complicações administrativas), o patrão tem que resolvê-lo, pelo menos em parte. O respeito permite compreender uma das formas de gestão da diferença social numa sociedade historicamente autoritária e profundamente desigual, na medida em que ele assegura a certeza, àqueles que estão abaixo na escala social - e que têm dúvidas quanto ao fato de pertencer plenamente à sociedade —, de que têm um lugar valorizado, mesmo que subalterno, dentro dessa sociedade. Mas o respeito também é reivindicado em nome do pertencimento ao gênero humano. $O$ que justifica a exigência de um tratamento respeitoso é o fato de ser "gente", o fato de pertencer à sociedade pelo cumprimento das "obrigações" indispensáveis à vida social. ${ }^{6}$ Como se vê, o respeito é uma categoria que se caracteriza pela ambivalência, revelando tanto o valor dado a relações fundadas num princípio hierárquico (marido-mulher, pai-filho, patrão-empregado) como o valor dado à igualdade.

Mas a noção de respeito envolve conexões com o deciframento da política. Trata-se de uma palavra muito utilizada na avaliação do comportamento dos políticos, pois, como já visto, eles têm "obrigações" específicas que devem cumprir em respeito ao povo. Todos os entrevistados concordavam com a idéia de que os políticos (freqüentemente identificados aos governantes) "não respeitam o povo" - mais exatamente, "não respeitam mais" ou "não respeitam como antigamente. Segundo Armando, "hoje, o governo não respeita mais o cidadão, ele não faz nada para os pobres. Os cidadãos são eles, os políticos. Mas o zé-qualquer, não tratam ele como cidadão." Ele não é tratado como cidadão "porque eles esqueceram as obrigações deles. Hoje, o político não cumpre mais seus deveres, não faz nada para os pobres, ele só pensa em roubar. Eu já te falei de Getúlio Vargas, de Juscelino eles fizeram muito para os pobres. Mas, hoje, os políticos esquecem."

O que se nota aqui é a pregnância da forma de legitimação política instaurada por Getúlio Vargas. Velhos e jovens, homens e mulheres, concordam: "Getúlio foi o melhor presidente do Brasil". 8 O desenvolvimento da legislação previdenciária e trabalhista durante o Estado Novo é tida como uma "doação de direitos aos pobres". Trata-se 
de uma referência central na memória política de muitos moradores de Brasília Teimosa.

Devido à forte degradação do ambiente econômico desde o início da década de 80 , os recursos de legitimação dos governantes diminuiram consideravelmente. Além de uma crise de legitimidade, o enfraquecimento da capacidade de intervenção do Estado produz um sentimento de perda de sentido dos sinais políticos instituídos. Daí decorre um dos principais problemas da instituição política do social e, portanto, da democracia no Brasil. Com efeito, sendo a esfera política decifrada através de obrigações morais derivadas das representações dos fundamentos do elo social, as atividades políticas nunca são verdadeiramente percebidas como uma esfera autônoma da vida social. Ou, como nesse período fundador do primeiro governo Vargas, a ação dos governantes é vista como a realização de uma obrigação e, neste caso, elo social e elo político se confundem. Ou, como hoje, a incapacidade dos eleitos em perpetuar essa forma de legitimação provoca o descrédito em relação aos políticos e às instituições políticas e, então, a política é vista como totalmente separada da vida respeitável, à qual os setores populares aspiram.

\section{O IMPACTO DA MÍDIA NO DECIFRAMENTO DA POLÍTICA}

Apesar de os moradores de Brasília Teimosa freqüentemente dizerem "não entender nada na política", eles recebem e restituem a informação política da mídia por meio de dispositivos cognitivos formados a partir de suas categorias de deciframento da política. Ao contrário do que o senso comum dos grupos mais favorecidos deixa a entender, eles não repetem passivamente as mensagens divulgadas pelo rádio e pela televisão. ${ }^{9}$ Como HOGGART (1957) mostrou, a propósito da recepção das mensagens culturais pelas classes populares inglesas, eles reinterpretam a informação política através de seu sistema de valores. Observa-se, também, que os mais críticos em relação ao políticos são aqueles que mais assistem aos noticiários televisivos e ao horário eleitoral gratuito durante as campanhas eleitorais, ${ }^{10}$ sendo que muitos gostam de imitar Boris Casoy, afirmando enfaticamente: "é uma vergonha", "é preciso passar o Brasil a limpo", "lugar de corrupto é a cadeia".

Para uma população que lê muito pouco jornais e revistas, o rádio e a televisão são efetivamente as principais fontes de informação política, permitindo um conhecimento relativo da esfera política. Enquanto apenas $59 \%$ dos favelados do Rio de Janeiro conheciam o nome do presidente da República no final da década de 60, (PERLMAN, 1977) todos os entrevistados de Brasília Teimosa sabiam quem era o presidente. No entanto, poucos conheciam mais de dois partidos políticos e a filiação partidária dos políticos mais conhecidos, o que, no final das contas, é bastante lógico num país em que o sistema partidário é particularmente fraco e em que os políticos mudam com freqüencia de partidos. A esse respeito, vale salientar que, longe de permitir uma representação melhor da diversidade dos interesses, a multiplicação dos partidos, a partir de 1979, parece ter criado uma desordem, causando uma certa inteligibilidade do sistema político. Quando havia apenas dois partidos, a ARENA representava o poder político ("o governo") e o MDB a oposição. Como explica Maria das Graças, "antigamente, na época do presidente militar, tinha dois partidos: na minha infância era ARENA e MDB. Depois, veio outros partidos. É difícil governar essas coisas. Hoje são milhares, que você não sabe o valor deles." Enfim, a dicotomia esquerda/direita quase nunca é utilizada para explicar a estruturação do campo político. Para a maioria dos entrevistados, uma pergunta sobre a diferença existente entre um político de esquerda e um político de direita não faz sentido, e os que respondem, freqüentemente opõem o "político justo", que "cumpre seus deveres", portanto "direito", ao "político errado", "de esquerda"."

De um modo geral, as informações do rádio e da televisão corroboram e reforçam as representações e as categorias de deciframento da política. Poucos entrevistados acreditavam nas promessas ("eles prometem mas não cumprem"). Quase todos viam a vida política como um jogo entre políticos e insistiam na falta de interesse dos eleitos pelos pobres.

\begin{abstract}
"No rádio, escuto $A$ hora do Brasil, que é às 7 horas. Escuto, e vejo muita crítica, e que o político está mais se preocupando não é com o interesse popular, mas com interesse na vida do outro político, do outro candidato. É como você vê essas campanhas ridículas, que eles não falam o que querem fazer com a população, para a população, mas se 'fulano roubou mais do que eu', 'fulano tem uma casa melhor', 'você viu o que ele fez antes' - como ele roubou menos ou como ele irá roubar mais. Os políticos não querem saber nada, eles só querem saber da vida do outro político." (Renata)
\end{abstract}

Eles também dão muita importância ao que os eleitos "fazem", o que explica o fato de conhecerem principalmente os nomes dos políticos que tiveram passagem por cargos executivos. Respondendo sobre quem consideram os políticos mais importantes, citam o presidente da República, o governador de Pernambuco, o prefeito do Recife e, raramente, deputados, senadores e vereadores.

Um dos resultados mais imprevistos da pesquisa diz respeito ao impacto do impeachment de Fernando Collor sobre as representações políticas de muitos moradores que votaram nele. Apesar de não ter participado das passeatas pelo impeachment, acompanharam o processo. A maioria dos que eram inicialmente contra a cassação de Collor passou a aprovar a decisão dos parlamentares. Entretanto, longe de ser interpretado como uma prova de moralização da política, o impeachment acentuou a desconfiança nas instituições políticas e no voto como meio de escolha de políticos. Na época de realização da pesquisa, era comum ouvir uma colocação como "depois de Collor, ninguém acredita". O que chama a atenção, aqui, é a denúncia da corrupção e, mais exatamente, a perda de legitimidade provocada pela revelação dos casos de corrupção. Em contraste, havia, até pouco tempo atrás, uma tolerância à corrupção, cujo melhor exemplo podia ser encontrado no 
famoso slogan de Ademar de Barros na década de 50: "Rouba mas faz." (BARBOSA, 1992, p.22)

A interpretação da informação eleitoral não difere fundamentalmente. Antes de mais nada, os moradores de Brasília Teimosa prestam atenção às realizações dos candidatos, às promessas não cumpridas lembradas pelos adversários no guia eleitoral e às acusações de corrupção. ${ }^{12}$ Os comentários sobre o horário eleitoral gratuito são os mesmos que aqueles que exprimem sobre as novelas: "gosto", "não gosto", "odeio". Muitos enfatizam que todos prometem a mesma coisa, o que comprova que "são todos mentirosos". Aliás, é forçoso constatar a semelhança das promessas eleitorais: o combate contra o desemprego, melhorias na educação e na saúde, a luta contra a violência e pela reforma agrária. Por ter observado a difusão do programa nos lares de Brasília Teimosa nas eleições de 1992 e 1994, constatamos essa atenção seletiva às mensagens políticas. Os comentários geralmente partem de fragmentos e nunca se esboçam discursos argumentados. Poucos candidatos são "bons", tal político é "ladrão", outro é "safado". Sem ilusões, muitos concordam: "de todo jeito, todos são iguais, nenhum presta; eles não fazem porra nenhuma".

\section{O ENFRAQUECIMENTO DA EFICÁCIA DAS PRÁTICAS CLIENTELISTAS}

O comportamento eleitoral dos setores populares brasileiros foi, freqüentemente, explicado pela noção de "clientelismo". Entretanto, observa-se derrotas de candidatos que recorrem a tais práticas, enquanto outros se elegem sem entrar nesse tipo de transação. ${ }^{13}$ Da mesma maneira, os dados colhidos sugerem que, mesmo que às vezes eles cheguem a pedir ajuda a políticos ou aceitem doações, os moradores de Brasília Teimosa não votam sistematicamente neles como contrapartida. Aqui, chama-se a atenção para a necessidade de abandonar, ou ao menos limitar, o uso da noção de clientelismo, na medida em que, mais uma vez, se verifica que o uso indiscriminado de um instrumento de análise impede que se realize uma análise com maior precisão. ${ }^{14}$ Esta pesquisa sugere, efetivamente, que a relação patrãocliente, que sustentava os "currais eleitorais" e o "voto de cabresto"nas campanhas nordestinas, não resistiu à urbanização. ${ }^{15}$

Num bairro como Brasília Teimosa, a diminuição da eficácia das práticas clientelistas pode ser explicada por seis fatores:

1) o descrédito em relação aos políticos tem um impacto sobre a interpretação das transações entre candidatos e eleitores durante o período eleitoral. Poucos eleitores vêem essas práticas como a manifestação do dever do político. Ao contrário, a maior parte dos entrevistados denunciava a "caça aos votos". As obras realizadas nos meses que antecedem as eleições também não iludem uma população acostumada a ver tais obras pararem pouco após o pleito;
2) a abundância das ofertas de transação. Na cidade, o eleitor pode escolher entre uma oferta eleitoral diversificada. Caso ainda não tenha uma relação patrãocliente, ela tende a perder a dimensão afetiva que existia antigamente no campo para tomar uma dimensão instrumental. ${ }^{16}$ Em Brasília Teimosa, constatamos que muitos moradores em busca de tijolos, sacos de cimento ou colchões vangloriavam-se de ter solicitado a vários candidatos simultanemente;

3) a impossibilidade de ter a certeza da lealdade de um eleitor. Os candidatos não dispõem da possibilidade de fiscalizar o voto de um cliente. Em Brasília Teimosa, muitos eleitores não votam nos candidatos que deram bens. Conforme um dos entrevistados, "eu acho que está melhorando, sabe, o brasileiro, ele está acordando. Porque antigamente um político chegava e iludia você com um saco de cimento. Hoje em dia, ele não ilude mais ninguém. Aquela pessoa pega o saco de cimento daquele camarada e não vota nele, manda ele para a puta que o pariu, e está certo. Está melhorando";

4) a multiplicação dos atores políticos num contexto de descentralização administrativa. O desenvolvimento da oferta eleitoral, com o fim do sistema bipartidário e a descentralização, produziu o enfraquecimento das máquinas políticas e a disseminação dos intermediários. Não há mais a situação de quase monopólio no acesso aos recursos públicos, que permitia a formação e a manutenção de redes de influência eleitoral. (DINIZ, 1982) Agora, a importância da barganha política entre o Executivo e os parlamentares provoca uma realocação desses recursos entre muitos políticos;

5) um aumento do custo das práticas clientelistas, provocado por duas razões: a forte concorrência entre políticos e a mudança das expectativas, devida à urbanização. Colocados em situação de concorrência pela generalização da dimensão instrumental na relação candidato-eleitor, os candidatos devem, com efeito, gastar muito para poder satisfazer um número suficiente de demandas, visando receber em troca os votos necessários ao sucesso eleitoral. Aliás, numa favela urbanizada como Brasília Teimosa, a estrutura das preferências dos moradores mudou com o passar do tempo e elevou o nível de exigências: eles não se satisfazem mais com a posse da terra, a instalação de esgotos ou o calçamento das ruas; hoje, eles pedem aos candidatos bolsas de estudos e, sobretudo, empregos, bens muito mais difíceis de serem distribuídos. Daí decorre um forte aumento das despesas eleitorais e, face a essas demandas, poucos candidatos dispõem dos recursos que permitem atender aos pedintes;

6) a evocação dos direitos do cidadão. $\mathrm{O}$ voto também é considerado um dos direitos do cidadão - entre os quais o "direito ao respeito" e "o direito à dignidade" se destacam - cuja utilização não depende, necessariamente, das medidas individuais ou coletivas tomadas por políticos.

Convém acrescentar que a maior parte dos moradores de Brasília Teimosa não considera o fato de ter recebido um bem ou uma ajuda de um político como o recebimento de um "favor" que estabelece uma relação de reciprocidade. A respeito desses bens e ajudas dispensados por políticos, sem 
pretender fazer uma tipologia, podemos distinguir analiticamente quatro atitudes, que diferem em função da idade e da situação socioeconômica, e nas quais encontramse os principais fatores de enfraquecimento das práticas clientelistas acima apontados:

1) Para uma minoria de moradores, essencialmente com mais de 60 anos, votar em quem "fez um favor" ou "ajudou" constitui uma obrigação moral do eleitor, que, por sua vez, "ajuda" e exprime sua gratidão. Quem "não dá o voto" em troca de uma ajuda recebida é um "ingrato". A importância dada à reciprocidade e à continuidade da relação faz com que apenas neste caso a relação candidato-eleitor apresente alguns elementos de uma relação de patronagem.

2) Entre os eleitores com menos de 40 anos, e também entre aqueles que enfrentam condições de vida particularmente precárias, o voto tende a ser considerado como um "bem de troca", no sentido apontado por QUEIROZ (1973). Nesta lógica, "é dando que se recebe", como se diz frequientemente em Brasília Teimosa para justificar a busca da transação eleitoral mais interessante.

3) Entre os jovens adultos e os que têm uma situação social relativamente boa em relação aos critérios locais, a idéia predominante é a de que as doações no período das campanhas eleitorais é um procedimento vergonhoso, financiado pelo dinheiro público desviado. No lugar de "favor", trata-se de uma "compra de votos" efetuada por políticos corruptos que tiram proveito da situação de necessidade de muitos eleitores. Conseqüientemente, não se pode aceitar uma transação dessas sem perverter a idéia de cidadania embutida no voto.

4) Outra minoria de moradores, geralmente jovens e com poucos recursos, julga que receber um bem não implica uma obrigação de lealdade eleitoral, na medida em que o candidato só faz restituir uma pequena parte do que ele "roubou". De qualquer forma, visto que os candidatos devem "dar alguma coisa" para se eleger, o fato de "ajudar" não é um critério para diferenciá-los. Além do mais, quem não vota num candidato em troca de um bem é freqüientemente tido como "esperto", "que engana os que enganam o povo".

\section{A ESCOLHA ELEITORAL}

A despeito do descrédito na política e da dúvida quanto à eficácia do voto como meio eficaz de mudar as condições de vida, os moradores de Brasília Teimosa votam. É certo que as taxas de abstenção e de votos nulos e brancos são um pouco mais altas no bairro do que no Recife, mas se trata de uma das características do comportamento eleitoral nas camadas de baixa renda. (ALKMIM, 1991, p.13-37) Nota-se, no entanto, um forte valor dado ao direito de voto, uma das marcas do reconhecimento de que se pertence plenamente à sociedade. ${ }^{17}$ Principalmente para os analfabetos, excluídos do sufrágio até 1985 , a obtenção deste direito político põe fim a uma situação de inferioridade jurídica e ao estigma que freqüentemente lhes vedava o acesso ao mercado do trabalho porque não possuíam título eleitoral. Conforme explicou Sebastião, "me interesso só quando chega o tempo para votar, que é um dever meu. Desde que os homens deram o direito ao analfabeto, eu tirei meu título. Quando chega o dia da eleição, eu vou votar. Futuramente, eu arranjo um negócio de emprego. Quando o cara procura saber meu título, eu não vou dizer que sou analfabeto. Meu interesse é votar."

Como nos Estados Unidos e na França, a abstenção, em Brasília Teimosa, pode remeter a duas razões: uma inserção social fraca ou um comportamento fundamentalmente político, que se manifesta na recusa voluntária de exprimir uma escolha política. (SUBILEAU \& TOINET, 1985) E os casos de votos nulos e brancos não são em nada diferentes. Para Isaura, "o voto é importante, mas do jeito que as coisas vão, o voto está cansado de ser enganado. Voto nulo."

Nesta última parte, vamos propor elementos de resposta à questão sobre os principais determinantes da escolha eleitoral em Brasília Teimosa.

Como é sabido, um determinante fundamental do comportamento eleitoral reside nas características dos métodos eleitorais. Tal observação vale particularmente no caso do Brasil, onde uma legislação complexa produz fortes efeitos no decorrer do processo eleitoral. A maioria desses efeitos foi analisada pelos cientistas sociais. (MAINWARING, 1991; LIMA JR., 1991) No entanto, um impacto negligenciado do sistema eleitoral no comportamento eleitoral está na compreensão diferenciada do método majoritário e do método proporcional. Trata-se, sem dúvida nenhuma, de um aspecto da lógica do voto em Brasília Teimosa a ser destacado antes de ir mais adiante na análise da escolha dos candidatos.

A respeito do método majoritário, pode-se dizer que os moradores do bairro, sem conhecer todas as suas especificidades, têm um conhecimento relativamente bom do mesmo. Explicam que "é o mais votado que se elege" e são capazes de citar os candidatos às eleições para presidente da República, governador e prefeito. O sistema de representação proporcional apresenta, ao contrário, um baixo grau de inteligibilidade. Dois aspectos da forma assumida por esse método no Brasil o explicam: o número muito elevado de candidatos e, sobretudo, a complexidade do processo de designação dos eleitos. Sobre o primeiro aspecto, vale notar que, apesar da presença de dezenas de cabos eleitorais em Brasília Teimosa, a maior parte dos candidatos é totalmente desconhecida: os entrevistados raramente conseguiam citar mais de cinco nomes e, depois do dia da eleição, freqüentemente não sabiam quais os candidatos eleitos e nem o resultado dos candidatos em que tinham votado. $\mathrm{O}$ acesso muito limitado ao horário eleitoral gratuito desses candidatos, a lentidão da apuração dos votos, o fato de que os resultados globais só são divulgados pelos diários e a primazia do Executivo sobre o Legislativo nas representações políticas podem ser apontados como as principais explicações. O segundo aspecto é o mais preocupante quanto à possibilidade de um melhor deciframento dos processos políticos e à própria inteligibilidade da democracia. Ele remete à total ignorância da maneira pela qual as cadeiras são preenchidas depois da obtenção do quociente eleitoral, do quociente partidário e 
da utilização das sobras. Com efeito, os moradores de Brasília Teimosa não apenas acreditam que, como no sistema majoritário, "é o mais votado que se elege", mas também não sabem que, votando num determinado candidato, eles podem contribuir para a eleição de um candidato em quem nunca teriam votado.

Da complexidade desse método proporcional decorrem os riscos de votos brancos e nulos, de erros e de recursos perante a Justiça Eleitoral, induzidos pela complexidade da utilização da cédula, outro aspecto menosprezado nas análises do comportamento eleitoral no Brasil. As observações realizadas nas sessões eleitorais de Brasília Teimosa revelaram, efetivamente, as dificuldades encontradas por muitos eleitores no preenchimento da cédula, tais como o esquecimento de nomes ou dos números dos candidatos e os erros ortográficos. ${ }^{18}$

$\mathrm{O}$ número elevado de candidatos às eleições proporcionais também reforça o papel dos cabos eleitorais na mobilização dos eleitores. Dadas a fraca institucionalização dos partidos e a visibilidade reduzida da competição às assembléias legislativas, o candidato que não dispõe desses agentes na coleta de votos tem poucas chances de ter uma votação expressiva nos bairros populares. Em Brasília Teimosa, esses political workers distribuem propanganda nas casas, mandam pintar os nomes dos candidatos nas paredes, organizam os comícios, lembram o "trabalho" que os candidatos "fizeram para o povo", recebem as demandas de ajuda (assistência administrativa, empregos, remédios, bolsas de estudo, material de construção) e distribuem bonés, camisetas e chaveiros. Inserido nas mesmas redes sociais que os eleitores (igreja, clube de futebol, grupo carnavalesco, clube de mães, associação de moradores, categoria profissional, etc.), o cabo eleitoral tenta convencêlos, em nome de sua participação nesses grupos, a votar no(s) candidato(s) pelo(s) qual/quais ele atua. Vale notar, entretanto, que muitos cabos eleitorais partilham a visão extremamente negativa da esfera política anteriormente evocada, e afirmam trabalhar para os candidatos unicamente pelo dinheiro. Alguns até conseguem ser contratados por vários candidatos, que, logicamente, ignoram tal situação. Em alguns casos, a busca de uma remuneração, a convicção política, a amizade e a lógica da troca se combinam. É o caso de Chico, cabo eleitoral de quatro candidatos à Câmara dos Vereadores: André Campos, que é quem o paga; o petista Paulo Rubem, em quem ele vota enquanto simpatizante do PT; o amigo Ivan Rodrigues; e Poluca, que deu camisas ao seu time, o Botafogo de Brasília Teimosa.

\footnotetext{
"Eu trabalhava pra André Campos porque estava precisando de dinheiro, desempregado. Fazendo boca de urna, estava também fazendo campanha pra outro, Paulo Rubem, do PT. Assim, quando não tinha ninguém [que trabalhava para o André Campos por perto] (...) já estava com o papel de Paulo Rubem, entregava e convencia a pessoa a votar em Paulo Rubem. Depois de doze horas, fui pra casa almoçar. Aqui, um colega meu era candidato a vereador: Ivan Rodrigues. Fiz campanha pra ele também (...) Naquele dia, fiz outra campanha pra vereador: para Poluca, que mora na Várzea - está financiando o time que eu faço parte (...) Os vereadores todos são concorrentes, mas eu tinha meu
}

político; meu político é aquele [gargalhadas]; 'Aqui [este] é ladrão; vote nesse, o Poluca'. Poluca fazia campanha pra ele: 'Ladrão por ladrão, Poluca é a solução'."

Por importante que seja, a coleta de votos dos cabos eleitorais não explica em si mesma o comportamento dos eleitores de Brasília Teimosa. Os resultados mostram que candidatos com exércitos de cabos eleitorais nem sempre conseguem muitos votos no bairro, enquanto outros, contando com poucos desses agentes políticos, obtêm uma boa votação. A respeito da escolha eleitoral, os dados concernem a quase 300 eleitores entrevistados nas eleições de 1992 e de 1994. Apesar da importância do material colhido, a análise do voto em Brasília Teimosa a partir das variáveis tradicionalmente utilizadas pela sociologia eleitoral (sexo, idade, ocupação, nível de instrução, nível de renda) foi bastante decepcionante. Com efeito, elas apenas permitiam estabeler correlações $(a)$ entre ser evangélico e votar nos candidatos a cargos legislativos apoiados pelos pastores, (b) entre ser evangélico e votar em Fernando Henrique Cardoso para presidente da República, e (c) entre a ocupação do candidato escolhido nas eleições proporcionais e a ocupação do eleitor. Além disso, a maior parte dos eleitores não levava em conta os partidos dos candidatos nem as incompatibilidades das alianças eleitorais nessas eleições. Comportamentos que correspondem à falta de conhecimento dos partidos. Era, portanto, impossível explicar o voto em Brasília Teimosa pela identificação partidária.

$\mathrm{Na}$ escolha eleitoral dos moradores de Brasília Teimosa, podia-se, entretanto, encontrar a distinção, estabelecida por Azis Simão num estudo sobre o voto dos operários paulistas na década de 50, entre "comportamento político" nas eleições a cargos executivos e "comportamento de simpatia" nas eleições a funções legislativas. (citado por TOURAINE, 1976, p.183). Quanto mais local a eleição, maior a importância de uma relação entre o candidato e o eleitor. Tanto mais que o fato de um partido ter um número de candidatos à mesma cadeira produz uma despolitização e uma territorialização da escolha, sendo o eleitor levado a escolher em função de critérios não partidários.

A despeito dessas duas racionalidades eleitorais, a escolha deriva, essencialmente, da imagem dos candidatos, construída através das categorias de deciframento da política. Os eleitores votam preferencialmente nos candidatos que "já fizeram" e comprovaram "experiência" e "competência". A idéia é que o candidato tem que "mostrar a folha de serviços" para merecer o voto. Os resultados da pesquisa em Brasília Teimosa comprovam que os cargos de direção nos órgãos públicos constituem, como RODRIGUES (1987) salientou, "plataformas de lançamento". Para deputado estadual, Gabriela votou em Cadoca, secretário de Turismo na prefeitura do Recife, porque "ele fez muita coisa pelo turismo; ele mostrou um trabalho muito bom." Segundo ela, "ele incentivou o turismo, gera muitos empregos. Organizou a Recifolia, que foi uma maravilha. Ele fez muita coisa para os recifenses se divertir."

A ênfase na "experiência" dos candidatos não remete apenas ao valor dado à capacidade de "fazer", mas também exprime o desejo de muitos eleitores, de evitar governantes 
irresponsáveis. O impacto desgastante do governo de Fernando Collor se tornou uma justificativa desse critério. Na medida em que "a falta de governo" é uma das explicações frequientemente mencionadas para dar conta dos problemas da sociedade brasileira, os eleitores dão preferência a candidatos identificados, que já atuaram conforme "as obrigações dos políticos”. Os candidatos acusados de corrupção podem pagar um preço alto, tal como, em Pernambuco, o ex-senador Ney Maranhão, que em 1994 não conseguiu sequer se eleger à Assembleia Legislativa do Estado. Em contraste, uma reputação de competência vale muitos votos. Foi o caso de Fernando Henrique Cardoso, cuja eleição é geralmente atribuída ao sucesso do Plano Real. Armando explica que votou em Fernando Henrique porque "entre todos, na minha opinião era o melhor." E era o melhor porque "eu não sei se o plano que ele criou foi eleitoreiro, mas pelo menos tivemos dois ou três meses feliz, as coisas mais baratas. Se depois acabar, foi um bom tempo que acabou-se logo."

\section{CONCLUSÃO}

A partir do caso de Brasília Teimosa não é possível, como já dissemos na introdução, construir uma quadro completo do comportamento eleitoral das camadas de baixa renda no Brasil urbano de hoje. A relevância dos resultados obtidos para uma teoria acabada do voto popular depende tanto de um trabalho comparativo com outros estudos localizados como do cruzamento das abordagens qualitativa e quantitativa. É mais adequado salientar os pontos aqui analisados que merecem inclusão numa agenda de pesquisas na qual seriam objeto de uma reflexão mais profunda.

O primeiro diz respeito à pregnância das categorias morais e do significado dado ao estilo de governo de Getúlio Vargas no deciframento da política. Caberia estudar mais fundo a correlação entre, por um lado, a retomada dessas categorias pelos candidatos e sua identificação (implícita ou explícita) a essa figura política e, por outro lado, os determinantes da escolha eleitoral.

O segundo concerne ao impacto da mídia. Sair da visão do papel diabólico da televisão constitui um primeiro passo, já dado por muitos analistas. Uma maior atenção às lógicas de recepção das mensagens políticas (durante as campanhas eleitorais e também fora delas) permitiria ir mais adiante. A utilização de vários métodos (questionário, observação, entrevistas individual e coletiva) é indispensável.

O terceiro reside na decomposição das antigas relações patrão-cliente herdadas do mundo rural, e remete à questão complexa da pluralidade das formas de se pertencer à sociedade e da diversidade das identidades sociais e políticas na cidade. Requer notadamente a não-separação do social e do político, ou seja, num plano acadêmico, ciência política e sociologia, ou sociologia política e sociologia urbana.

O quarto refere-se aos efeitos sobre a escolha eleitoral na complexidade do sistema eleitoral e da cédula, visto que, em muitos casos, a peculiaridade dos resultados ou as taxas de votos nulos e brancos não resultam apenas da incapacidade política dos eleitores, e sim da própria legislação eleitoral.

\section{NOTAS}

1 Este texto condensa algumas idéias desenvolvidas em tese de doutoramento em Sociologia orientada por Daniel Pécaut na École des Hautes Études en Sciences Sociales, publicada pela Maison des Sciences de l'Homme. (VIDAL, 1998)

2 A esse respeito, ver os artigos reunidos por REVEL (1996).

3 Nota-se que a expressão "Chegou a época da política" também foi registrada por PALMEIRA \& HEREDIA (1993) no interior de Pernambuco.

${ }^{4}$ Esse fato aponta para as limitações do valor científico de análises feitas a partir de pesquisas quantitativas sobre a preferência pela democracia ou pela ditadura.

${ }^{5}$ Nos limites deste texto, não podemos examinar a especificidade e a complexidade dos usos da categoria "respeito" nos discursos dos moradores de Brasília Teimosa. Para uma análise mais detalhada, consultar VIDAL (1998).

${ }^{6}$ É por isso que a maioria dos moradores de Brasília Teimosa concordam com a violência da polícia contra os delinqüentes ou com a barbaridade do sistema penitenciário. Pelo fato de ter um comportamento opondo-se ao ideal de relações sociais fundadas na confiança e na conviviabilidade, o "marginal" sai do quadro da humanidade, não passa de um "animal" (geralmente, um "cachorro") e, conseqüientemente, não pode ser tratado como "gente".

${ }^{7}$ Os nomes de pessoas grafados em itálico, no texto, referem-se a pessoas entrevistadas.

8 A respeito da noção de legitimação, ver LAGROYE (1985).

9 Contra essa visão mainstream da influência da mídia, que se encontra em muitos países, ver GAMSON (1992).

${ }^{10} \mathrm{~A}$ partir de uma pesquisa realizada em várias regióes do Brasil, Conrad P. Kottak enfatiza esta correlação entre o número de horas passadas vendo televisão e a falta de confiança no governo como sendo "o maior impacto da televisão sobre todas as formas de crença”. (KOTTAK, 1991, p.78)

"Sobre o processo de constituição da dicotomia esquerda/direita, ver GAUCHET (1992, p.394-467). Nota-se que a incapacidade de definir a esquerda e a direita também se encontra em países onde a competição política é historicamente mais estável. (BUTLER \& STOKES, 1969)

${ }^{12}$ Sobre a influência da televisão no comportamento eleitoral, ver STRAUBHAAR et al (1993) e SILVA (1993).

${ }^{13}$ Como bem o apontou George Avelino Filho, a forte taxa de renovação na Câmara dos Deputados e nas assembléias legislativas, observada em todos os Estados, revela que a utilização eleitoreira de recursos públicos não garante a reeleição, o que contradiz a tese segundo a qual a vida política brasileira está nas mãos de oligarquias regionais que controlam clientelas. (AVELINO FILHO, 1994, p.225-240)

${ }^{14}$ Jean-François Médard define a relação de clientela ou patronagem como "uma relação de dependência pessoal não ligada ao parentesco que reside numa troca recíproca de favores entre duas pessoas, o patrão e o cliente, que controlam recursos desiguais." (MÉDARD, 1976, p.103) Para Gellner, "o termo clientelismo (ou, ainda, patronagem) designa um certo tipo de relação política, ou seja, a relação, de caráter dissimétrico, existente entre um patrão e um cliente, na qual o primeiro traz sua proteção ao segundo enquanto este oferece seu apoio em retorno, e se estabelece num estado de relativa submissão." (GELLNER, 1991, p.563564)

${ }^{15}$ Sobre as formas de dominação política que existiam (e ainda existem em vários lugares) no interior do Brasil, ver LEAL (1986) e GRAHAM (1990).

${ }^{16}$ Há mais de vinte anos atrás, em Santa Brígida, povoado do norte da Bahia, o eleitor já tendia a utilizar seu voto como um "bem de troca". (QUEIROZ, 1973)

${ }^{17}$ Como nos casos francês e americano, o contraste entre o que estava em jogo nas lutas pelo direito de voto e no absencionismo mais forte nos grupos que acabavam de conquistá-lo provém da dimensão de integração simbólica de integração social em posição de iguais que esse direito 
tinha para os que não faziam parte do corpo político. (ROSANVALLON, 1992; SHKLAR, 1991)

${ }^{18}$ É certo que para um observador francês, acostumado a votar com cédulas impressas com o nome do candidato ou da chapa, o ato de votar parece singularmente complicado no Brasil, em particular para os eleitores que não dominam bem o português escrito. A respeito da evolução das práticas eleitorais na França, ver GARRIGOU (1992) e ROSANVALLON (op. cit.).

\section{REFERÊNCIAS BIBLIOGRÁFICAS}

ALKMIM, A. C. R. A participação eleitoral e seus correlatos sócioeconômicos. In: LIMA JR. O. (ed.). Sistema eleitoral brasileiro. Teoria e prática. Rio de Janeiro: Iuperj/Rio Fundo Editora, 1991. p.13-37.

AVELINO FILHO, G. Clientelismo e política no Brasil. Revisitando velhos problemas. Novos Estudos Cebrap, n. 38, p.225-240, mar. 1994.

BARBOSA, L. O jeitinho brasileiro. A arte de ser mais igual que os outros. Rio de Janeiro: Campus, 1992.

BUTLER, D. \& STOKES, D. Political change in Britain. Forces shaping electoral choice. London: MacMillan/St. Martin Press, 1969.

CALDEIRA, T. O cotidiano dos moradores da periferia e o que pensam do poder e dos poderosos. São Paulo: Brasiliense, 1984.

DINIZ, E. Voto e máquina política. Patronagem e clientelismo no Rio de Janeiro. Rio de Janeiro: Paz e Terra, 1982.

GAMSON, W. Talking politics. Cambridge: Cambridge University Press, 1992.

GARRIGOU, A. Le vote et la vertu. Comment les français sont devenus électeurs. Paris: Presses de la Fondation Nationale des Sciences Politiques, 1992.

GAUCHET, M. La droite et la gauche. In: NORA, P. (ed.). Les lieux de mémoire, III. Les France 1. Conflits et partages. Paris: Gallimard, 1992. p.394-467.

GELLNER, E. Patronage. In: BONTE, P. \& IZARD, M. (eds.). Dictionnaire de l'ethnologie et de l'anthropologie. Paris: PUF, 1991.

GRAHAM, R. Patronage and politics in the nineteenth-century Brazil. Stanford: Stanford University Press, 1990.

HOGGART, R. The uses of literacy. London: Chatto and Windus, 1957.

KOTTAK, C. P. Television's impact on values and local life in Brazil. Jornal of Communications, v. 41, n. 1, winter. 1991.

LAGROYE, J. La légitimation. Traité de science politique. Tome 1. Paris: PUF, 1985. p.395-467.

LEAL, V. N. Coronelismo, enxada e voto. O município e o regime representativo no Brasil. São Paulo: Alfa-Ômega, 1986. (1949)

LIMA JR. O. (ed.). Sistema eleitoral brasileiro. Teoria e prática. Rio de Janeiro: Iuperj/Rio Fundo Editora, 1991.

MAINWARING, S. Políticos, partidos e sistemas eleitorais. O Brasil numa perspectiva comparativa. Novos Estudos Cebrap, n. 29, p.34-58, mar. 1991.

MÉDARD, J. F. Le rapport de clientèle: du phénomène social à l'analyse politique. Revue Française de Science Politique, v. 26, n. 1, p.103124, fév. 1976

PALMEIRA, M. \& HEREDIA, B. Le temps de la politique. Études Rurales, n. $131-132$, p.73-87, 1993.

PERLMAN, J. O mito da marginalidade. Favelas e política no Rio de Janeiro. Rio de Janeiro: Paz e Terra, 1977.

QUEIROZ, M. I. P. de. Política, ascensão social e liderança num povoado baiano. In: O campesinato brasileiro: ensaios sobre civilização e grupos rústicos no Brasil. Petrópolis: Vozes, 1973. p.100-122.

REVEL, J. (ed.). Jeux d'échelles. La micro-analyse à l'expérience. Paris: Seuil/Gallimard, 1996.
RODRIGUES, L. M. Quem é quem na Constituinte. Uma análise sóciopolítica dos partidos e deputados. São Paulo: OESP-Maltese Editores, 1987.

ROSANVALLON, P. Le sacre du citoyen. Histoire du suffrage universel en France. Paris: Gallimard, 1992.

SHKLAR, J. La citoyenneté américaine. La quête de l'intégration. Paris: Calmann-Lévy, 1991.

SILVA, C. E. Lins da. The brazilian case: manipulation by the media? In: SKIDMORE, T. (ed.). Television, politics and the transition to democracy in Latin America. Baltimore/London: The John Hopkins University Press, 1993. p.137-144.

STRAUBHAAR, J. et al. The brazilian case: influencing the voter. In: SKIDMORE, T. (ed.). Television, politics and the transition to democracy in Latin America. Baltimore/London: The John Hopkins University Press, 1993. p.118-136.

SUBILEAU, F. \& TOINET, M. F. L'abstentionnisme en France et aux ÉtatsUnis: méthodes et interprétations. In: GAXIE, D. (ed.). Explication du vote. Un bilan des études électorales en France. Paris: Presses de la Fondation Nationale des Sciences Politiques, 1985. p.175-198.

TOURAINE, A. Les sociétés dépendantes. Gembloux: Duculot, 1976.

VIDAL, D. La politique au quartier. Rapports sociaux et citoyenneté à Recife. Paris: Éditions de la Maison des Sciences de l'Homme, 1998. 